\title{
РОЛЬ ПОДАТКУ НА ПРИБУТОК ПДПРИЕМСТВ В ФОРМУВАННІ БЮДЖЕТУ КРАЇНИ
}

\section{Хорошилова І.О., канд. екон. наук, доцент Харківський національний автомобільно-дорожсній університет}

Постановка проблеми. Податок на прибуток підприємств на сьогодні $\epsilon$ одним з найвагоміших із групи прямих податків у податковій системі України, ефективність механізму його нарахування та відповідно й результативність фіскальної політики держави має суттєвий вплив на фінансово економічну діяльність суб' єкту господарювання. Тому покращення його сучасного стану це одна 3 найважливіших соціально-економічних проблем, від швидкого вирішення яких значною мірою залежить подальший розвиток малого та середнього бізнесу в Україні. Економіка України динамічно розвивається та постійно потребує приведення податкової системи та законодавства у відповідність до економічних умов сьогодення. Останні зміни у податковому законодавстві щодо гармонізації бухгалтерського обліку та податкових розрахунків дають підставу значно детальніше дослідити методику оприбуткування податку на прибуток.

Аналіз останніх досліджень і публікацій. Податок на прибуток підприємства фактично є податком на фінансовий результат що формується в обліку за підсумками всіх господарських операцій суб'єкту виконаних ним у звітній період. Даним питанням переймаються не тільки науковці, а й законодавчі органи та податківці, й платники податку, й фінансисти, та навіть юристи. Серед вітчизняних вчених, які присвятили свої роботи дослідженню проблематики оподаткування прибутків слід відзначити В. Андрущенко, П. Герасименко, А. Крисоватий, М. Пасько, М. Проданчук, О. Сидорович, А. Ткаченко, Н. Ярошевич та інші. Узагальнюючі ці напрацювання можна стверджувати що нажаль стан та механізм оприбуткування даного податку, як суттєвої складової доходної частини бюджету України, не відповідають критеріям та вимогам що висуваються в розвинених країнах з стабільною економікою. Тому це питання $є$ актуальним, має велику значимість, та потребує детального дослідження.

Невирішені складові загальної проблеми. Податок на прибуток - це прямий податок, який сплачують підприємства 3 прибутку, що $є$ перевищенням суми доходів над собівартістю реалізованої продукції, а також над сумою інших витрат звітного періоду [3]. Згідно зі ст. 134 нової редакції Податкового Кодексу України [1], об єктом оподаткування податку на прибуток є прибуток iз джерелом походження з України та за ії межами, який визначається шляхом коригування (збільшення або зменшення) фінансового результату до оподаткування (прибуток або збиток), визначеного у фінансовій звітності 
підприємства відповідно до НП(С)БО або МСФЗ, на різниці. Тобто ст. 134 узаконила новий підхід до формування об`єкта оподаткування, котрий тепер складається 3 двох частин: фінансового результату до оподаткування та різниць.

Відображення суми витрат 3 податку на прибуток на рахунках бухгалтерського обліку це один із завершальних етапів облікових процедур 3 обліку податку на прибуток. Йому передує складний комплекс робіт щодо визначення фінансового результату до оподаткування прибутку (збитку). Тобто прибуток підприємства в дійсності складається 3 доходів підприємства за вирахуванням витрат. I перш ніж бухгалтер перейде до визначення суми та облікового відображення податку на прибуток, необхідно достовірно визначити які доходи та витрати виникали у відповідному звітному періоді.

Формулювання цілей статті. Метою статті $є$ аналізі сучасного стану податку на прибутку підприємств в державі та обгрунтування його ролі в формуванні доходної частини державного бюджету за для досягнення оптимальності співпадіння інтересів учасників податкових відносин.

Виклад основного матеріалу дослідження. Оскільки податок на прибуток підприємств є одним 3 чотирьох основних бюджетоутворюючих податків поряд з податком на додану вартість, податком на доходи фізичних осіб та акцизним податком. А основним призначення його $€$ регулювання господарської діяльності, стимулювання розвитку інвестицій та нарощення капіталу підприємства [4], але ми бачимо, що сучасний стан прибуткового оподаткування не відповідає покладеним на нього завданням. Про це свідчить зниження фіскальної ефективності податку на прибуток, тобто зниження його частки у ВВП, доходах бюджету та податкових надходженнях. По перше звернемо увагу на організацію та методику бухгалтерського обліку податку на прибуток на підприємстві, зображену на рис. 1.

Облік суми витрат 3 податку на прибуток ведеться на рахунку 98 «Податок на прибуток». За дебетом рахунку відображаються нараховані суми податку на прибуток, відрахувань до Державного бюджету України від доходів, від проведення державних грошових лотерей і податку на доходи від страхової діяльності, за кредитом - включення до фінансових результатів на рахунку 79 «Фінансові результати». До даного рахунку аналітика не передбачена, тому $є$ необхідність введення нових субрахунків залежно від виду діяльності, від якого виникають такі витрати, або за ставками податку, якщо на підприємстві застосовується декілька таких. Дані рахунку 98 «Податок на прибуток» знаходять відображення в Журналі 5 (5A) та у формах річної фінансової звітності. Також на підприємстві можуть бути форми внутрішньої звітності про нарахування та сплату податку на прибуток для підвищення ефективності управління ним та податкової оптимізації [3]. 


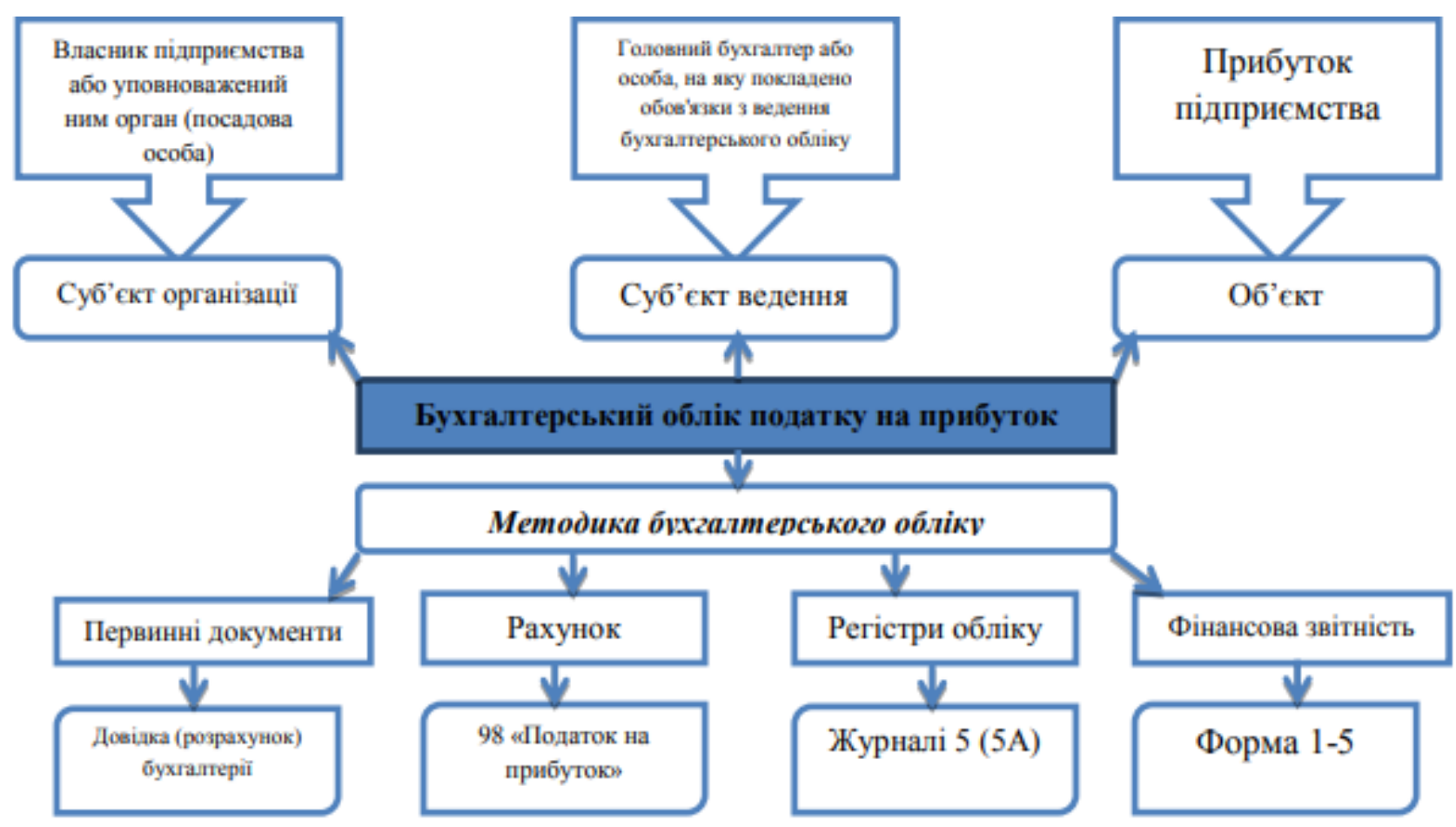

Рис. 1. Організація і методика бухгалтерського обліку податку на прибуток

Джерело: адаптовано автором на основі [4]

Спільна риса обох видів обліку полягає в тому, що податкове та бухгалтерське законодавство має подібну мету та завдання: формування достовірної інформації про фінансові результати діяльності та для цілей контролю дотримання законодавства. 3 моменту прийняття Податкового кодексу України $\epsilon$ низка принципів, властивих як бухгалтерському, так i податковому обліку, таких як періодичність, автономність, єдиний грошовий вимірник, безперервність, послідовність, відповідність доходів і витрат. Принцип відповідності доходів і витрат бухгалтерського обліку покладено в основу обчислення об'єкта оподаткування податком на прибуток підприємств.

Забезпечення справляння податку на прибуток підприємств $\epsilon$ гармонізація податкового і бухгалтерського обліку. Принцип гармонізації передбачає в подальшому формування єдиного понятійного апарату для бухгалтерського обліку та податкової системи, що дасть змогу ліквідувати суперечності між ними. Однак навіть гармонізована система передбачає наявність тимчасових і постійних податкових різниць. Отже, податок на прибуток підприємств не зумовлює об‘єктивної потреби у веденні автономного податкового обліку, адже це спричинить значні зміни як для підприємства, так і для держави [3].

Як мі вже зазначали, податок на прибуток - один з найпопулярніших податків у світі, в Україні ж він займає четверте місце за значущістю у доходах Державного бюджету України (рис.2.). 
Надходжень від податку на прибуток підприємсте до бюджету Украйни $3 a 2007-2017 \mathrm{pp}$.

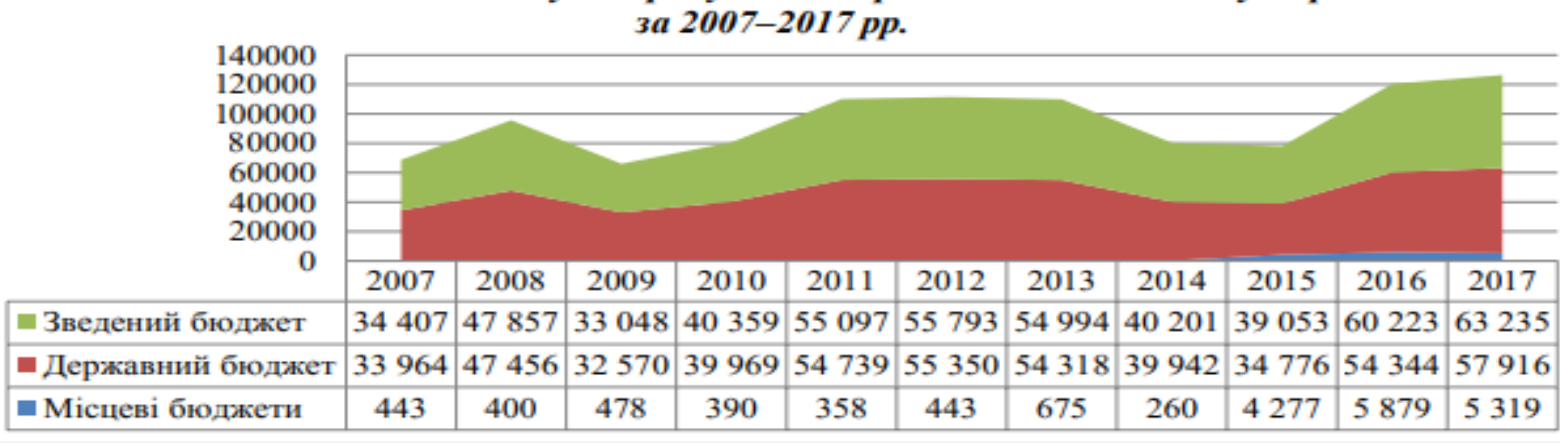

\section{Рис. 2. Динаміка обсягу надходжень від податку на прибуток підприємств до бюджету України за 2007-2017 рр., млн. грн.}

\section{Джерело: сформовано автором за даними [2]}

В структурі доходів зведеного та державного бюджетів України податок на прибуток поступається тільки податку на додану вартість та податку на доходи фізичних осіб. Податок на прибуток підприємств в Україні має багато спільних рис з податком на прибуток корпорацій в зарубіжних країнах. Його надходження в доходах бюджетів зарубіжних країн становлять незначну частину, однак, не дивлячись на це, податок на прибуток корпорацій виконує важливу роль економічного регулятора. Регулююча функція податку на прибуток проявляється в оптимізації податкових ставок та різного роду податкових пільгах, при чому ефективність останніх безпосередньо залежить від способу надання та відповідного контролю [5].

В нашій країні ми спостерігали поступове зменшення ставки податку на прибуток, в теперішній час поточна ставка податку на прибуток становить 18 $\%$. Цей показник є меншим ніж у більшості країн Європи, що дає нам можливість залучати іноземні інвестиції. Зменшення ставки податку $\epsilon$ загальноєвропейською тенденцією [3], але також звернемо увагу, що при незмінності інших умов подальше зниження може не дати очікуваного економічного ефекту, як приклад згадаємо податкові пільги, які, призводячи до значних втрат бюджету, не стали каталізатором економічного розвитку країни для цього потрібно провести значно глибші реформи. Потрібно й надалі впроваджувати конструктивні кроки в напрямі гармонізації податкового та бухгалтерського обліку з податку у напрямі скорочення кількості розбіжностей між ними; переглянути пільги 3 метою ліквідації тих, що не дали адекватного економічного 3 часу їх запровадження; посилити підтримку інвестиційноінноваційної діяльності.

На наш погляд це в сукупності 3 напрямами Програми економічних реформ $є$ актуальними кроками, що здатні створити сприятливі умови для ведення ділової активності та покращення фінансово-економічного стану підприємствами України без шкоди для показників державного бюджету. 
Висновки 3 проведеного дослідження. Отже, сучасний облік податку на прибуток має свої недоліки. Необхідно гармонізувати правила ведення бухгалтерського фінансового обліку на законодавчому рівні. Щодо частки податку на прибуток підприємства в надходженнях України, то він посідає четверте місце, що свідчить про зменшення частки цього податку в надходженнях до бюджету. Все це пояснюється тим, що країна переходить від суто фіскальної до стимулюючої системи оподаткування підприємств. Цей процесу виявився дуже складним та болючім, бо реформування відбувається в умовах економічної кризи спричиненої пандемією, що породжує дефіцит державних фінансових ресурсів. То ж ми спостерігаємо суттєве зниження фіскальної значимості податку на прибуток, який утратив статус основного бюджетоформуючого податку. Але не варто очікувати що зміни окремих елементів податку підвищать його фіскальну ефективність та спрощують процедуру обчислення податкового зобов'язання i формування податкової звітності. Тому необхідні кардинальні зміни насамперед до підходу оподаткування прибутку підприємств.

\section{Перелік посилань}

1. Податковий кодекс України: прийнятий Верховною Радою України 2 грудня 2010 p. № 2755-VII, змін. станом на 01.01.2017: URL: http://zakon3.rada.gov.ua/laws/show/2755-17/page23 (дата звернення: 27.08.2021).

2. Податкові надходження: веб-сайт. URL: http://cost.ua/budget/revenue/ (дата звернення 27.08.2021).

3. Проданчук М. А. Шляхи вдосконалення відображення інформації про результати діяльності у фінансовій звітності Фінанси України. 2014. № 7. C. 99-113. URL: http://nbuv.gov.ua/UJRN/Fu_2014_7_10 (дата звернення: 16.09.2021).

4. Герасименко П. Податок на прибуток - чинник стимулювання економіки. URL: http://zaxid.net/home/show (дата звернення: 28.08.2021).

5. Дубовик О.Ю., Генна Л.О. Реалізація регулюючої функції податку на прибуток в Україні. Науковий вісник. Одеський державний економічний університет. Всеукраӥнська асоиіація молодих науковиів. Науки: економіка, політологія, історія. 2015. № 3(223). С. 65-77.

6. Державна фіскальна служба України: веб-сайт. URL: http://sfs.gov.ua/ (дата звернення: 17.09.2021).

7. Хомутенко В.П., Хомутенко А.В. Фрагментарний аналіз механізму дії регулюючої функції податку на прибуток підприємств в Україні. Evropský časopis ekonomiky a managementu. 2017. № 1. C. 230.

8. Гороховська Ю. І., Чигрин В. В. Податок на прибуток підприємств як інструмент наповнення бюджету. Глобальні та національні проблеми економіки. 2015. Вип. 5. С. 4-8.

9. Дєєва Н. М., Редіна Н. І. Оподаткування в Україні: навч. посіб. Київ: Центр учбової літератури, 2010. 544 c. URL: https://www.twirpx.com/file/190860 . (дата звернення: 16.09.2021). 
10. Непочатенко О. О., Боровик П. М., Щепелюк Б. Р. Оподаткування прибутку підприємств в Україні. Економіка. Управління. Інновації. 2015. №1. URL: http://nbuv.gov.ua/UJRN/eui_2015_1_28 (дата звернення: 28.08.2021).

11. Офіційний сайт Державної казначейської служби України: веб-сайт. URL: http://www.treasury.gov.ua (дата звернення: 17.09.2021).

\section{References}

1. Tax Code of Ukraine: adopted by the Verkhovna Rada of Ukraine on December 2, 2010 № 2755-VII, amendments. as of 01.01.2017: [Podatkovy`j kodeks Ukrayiny`: pry`jnyaty`j Verxovnoyu Radoyu Ukrayiny` 2 grudnya 2010 r. \# 2755VII, zmin. stanom na 01.01.2017], available at: http://zakon3.rada.gov.ua/laws/show/2755-17/page23 (last accessed 27.08.2021).

2. Tax revenues. [Podatkovi nadxodzhennya]: website, available at: http://cost.ua/budget/revenue/ (last accessed 27.08.2021).

3. Prodanchuk M.A. (2014). Ways to improve the reflection of information about the results of tivities in the financial statements Finance of Ukraine. [Shlyaxy' vdoskonalennya vidobrazhennya informaciyi pro rezul taty` diyal`nosti u finansovij zvitnosti] Finance of Ukraine, available at: No 7, P. 99-113. http://nbuv.gov.ua/UJRN/Fu_2014_7_10 (last accessed 16.09.2021).

4. Gerasimenko, P. Income tax - a factor stimulating the economy. [Podatok na pry`butok pidpry`yemstv yak instrument napovnennya byudzhetu], available at: http://zaxid.net/home/show (last accessed 28.08.2021).

5. Dubovyk, O. Iu., Henna, L. O. (2015). Implementation of the regulatory function of income tax in Ukraine [Realizatsiia rehuliuiuchoi funktsii podatku na prybutok v Ukraini]. Scientific Bulletin. Odessa State Economic University. AllUkrainian Association of Young Scientists. Sciences: economics, political science, history, No 3(223), P. 65-77.

6. State Fiscal Service of Ukraine. [Derzhavna fiskal'na sluzhba Ukrayiny], available at: http://sfs.gov.ua/ (last accessed: 17.09.2021).

7. Khomutenko, V.P, Khomutenko A.V. (2017). Fragmentary analysis of the mechanism of action of the regulatory function of corporate income tax in Ukraine. [Fragmentarny`j analiz mexanizmu diyi regulyuyuchoyi funkciyi podatku na pry`butok pidpry`yemstv v Ukrayini]. Evropský časopis ekonomiky a managementu. No $1,230 \mathrm{p}$.

8. Horokhovska, Yu. I. \& Chyhryn, V. V. (2015). Corporate income tax as a tool for filling the budget [Podatok na prybutok pidpryiemstv yak instrument napovnennia biudzhetu]. Global and national problems of the economy, 5, P.4-8

9. Dieieva, N. M. \& Redina, N. I. (2010). Taxation in Ukraine [Opodatkuvannia v Ukraini]. Kyiv: Tsentr uchbovoi literatury. 544p., available at: https://www.twirpx.com/file/190860/ (last accessed 16.09.2021).

10. Nepochatenko, O. O., Borovyk, P. M. \& Shchepeliuk, R. B. (2015). Taxation of corporate profits in Ukraine [Opodatkuvannia prybutku pidpryiemstv $\mathrm{v}$ Ukraini]. Economy. Management. Innovations, 1, available at: $\mathrm{m}$ http://nbuv.gov.ua/UJRN/eui_2015_1_28 (last accessed 28.08.2021). 
11. Official site of the State Treasury Service of Ukraine [Ofitsiinyi sait Derzhavnoi kaznacheiskoi sluzhby Ukrainy]: website, available at: http://www.treasury.gov.ua. (last accessed 17.09.2021).

\section{РЕФЕРАТИ РЕФЕРАТЫ ABSTRACTS}

\section{УДК 336.2.026; JEL Classification: M48 \\ ХорошиЛова І.О. РОЛЬ ПОДАТКУ НА ПРИБУТОК ПІДПРИМСТВ В ФОРМУВАННІ БЮДЖЕТУ КРАЇНИ}

Mema дослідження $\epsilon$ аналіз сучасного стану податку на прибуток підприємств в державі та обгрунтування його ролі в формуванні державного бюджету. Методика дослідження: для досягнення поставленої мети в роботі були використані такі загальнонаукові та спеціальні методи і прийоми дослідження: порівняльний аналіз наукової літератури та інформаційних джерел на основі методів порівняння, систематизації та узагальнення; узагальнення результатів аналізу і логічна генерація висновків. Результати дослідження: результатом наукової роботи $\epsilon$ теоретичне узагальнення i практичні рекомендації щодо обліку та оприбуткування податку на прибуток підприємств. Сучасний облік податку на прибуток має свої недоліки. Необхідно гармонізувати правила ведення бухгалтерського фінансового обліку на законодавчому рівні. Наукова новизна: полягає в комплексному дослідженні проблем, пов'язаних 3 обліком оприбуткування податку на прибуток підприємств. Запропоновано й надалі впроваджувати конструктивні кроки в напрямі гармонізації податкового та бухгалтерського обліку 3 податку у напрямі скорочення кількості розбіжностей між ними. Все це зумовлено переходом від суто фіскальної до стимулюючої системи оподаткування підприємств, в умовах економічної кризи спричиненої пандемією, що породжує дефіцит державних фінансових ресурсів. Практична значущість полягає в тому, що з впровадженням актуальних кроків в системі оподаткування та законотворенні виникнуть сприятливі умови для ведення ділової активності та покращення фінансово-економічного стану підприємствами України без шкоди для показників державного бюджету.

Ключові слюва: податок; податкова система; облік; бюджет; ефективність підприємства.

\section{УДК 336.2.026; JEL Classification: M48}

Хорошилова И.А. РОЛЬ НАЛОГА НА ПРИБЫЛЬ ПРЕДПРИЯТИЙ В ФОРМИРОВАНИИ БЮДЖЕТА СТРАНЫ

Целью исследования является анализ современного состояния налога на прибыль предприятий в стране и обоснование его роли в формировании государственного бюджета. Методика исследования: для достижения поставленной цели в работе были использованы такие общенаучные и 
специальные методы и приемы исследования: сравнительный анализ научной литературы и информационных источников на основе методов сравнения, систематизации и обобщения; обобщение результатов анализа и логическая генерация выводов. Результаты исследования: результатом научной работы является теоретическое обобщение и практические рекомендации по учету и оприходованию налога на прибыль предприятий. Современный учет налога на прибыль имеет свои недостатки. Необходимо гармонизировать правила ведения бухгалтерского финансового учета на законодательном уровне. Научная новизна: заключается в комплексном исследовании проблем, связанных с учетом оприходования налога на прибыль предприятий. Предложено и в дальнейшем внедрять конструктивные шаги в направлении гармонизации налогового и бухгалтерского учета в направлении сокращения количества разногласий между ними. Все это обусловлено переходом от сугубо фискальной к стимулирующей системе налогообложения предприятий, в условиях кризиса экономики чему способствовала пандемия, что порождает дефицит государственных финансовых ресурсов. Практическая значимость заключается в том, что с внедрением актуальных шагов в системе налогообложения возникнут благоприятные условия для ведения деловой активности и улучшение финансово-экономического состояния предприятиями Украины без ущерба для показателей государственного бюджета.

Ключевые слова: налог; налоговая система; учет; бюджет; эффективность предприятия.

\section{UDK 336.2.026; JEL Classification: M48 \\ Khoroshylova I.O. THE ROLE OF THE INCOME TAX IN THE FORMATION OF THE COUNTRY BUDGET}

Purpose the study analyzes the current state of corporate income tax in the state and substantiates its role in the formation of the state budget. Methodology of research: to achieve this goal in the work were used the following general and special research methods and techniques: comparative analysis of scientific literature and information sources based on methods of comparison, systematization and generalization; generalization of analysis results and logical generation of conclusions. Findings: the result of scientific work is a theoretical generalization and practical recommendations for accounting and accounting for corporate income tax. Modern income tax accounting has its drawbacks. It is necessary to harmonize the rules of financial accounting at the legislative level. Originality: is a comprehensive study of the problems associated with the accounting of income tax. It is proposed to continue to implement constructive steps towards the harmonization of tax and tax accounting in the direction of reducing the number of differences between them. All this is due to the transition from a purely fiscal to a stimulating system of corporate taxation, in the economic crisis caused by the pandemic, which creates a shortage of public financial resources. Practical value: is that with the introduction of relevant steps in the system of taxation and legislation will create favorable conditions for 
doing business and improving the financial and economic condition of Ukrainian enterprises without compromising the state budget.

Key words: tax; the tax system; accounting; budget; efficiency of the enterprise.

\section{Відомості про авторів / Сведения об авторах / About the Authors}

Хорошилова Ірина Олександрівна - кандидат економічних наук, доцент, Харківський національний автомобільно-дорожній університет, доцент кафедри обліку і оподаткування, м. Харків, Україна; e-mail: hia23@ukr.net; ORCID: https://orcid.org/0000-0001-5343-5161. Моб. 050-307-97-03.

Хорошилова Ирина Александровна - кандидат экономических наук, доцент, Харьковский национальный автомобильно-дорожный университет, доцент кафедры учета и налогообложения, г. Харьков, Украина.

Khoroshylova Iryna Oleksandrovna - Candidate of Sciences (Economics), Kharkov National Automobile and Highway University, Associate Professor at the Department of account, taxation, Kharkiv, Ukraine. 